\title{
Pengetahuan tentang osteoporosis yang rendah menurunkan konsumsi susu pada murid SMA
}

\author{
Intan Aru Palaka ${ }^{1}$ Adi Hidayat ${ }^{2}$
}

\begin{abstract}
ABSTRAK
\section{LATAR BELAKANG}

Susu merupakan sumber utama kalsium dan fosfor yang sangat penting untuk pembentukan tulang. Susu sangat baik dikonsumsi pada masa remaja, karena pada masa remaja terjadi pembentukan jaringan tulang yang merupakan masa persiapan untuk mencapai puncak pertumbuhan massa tulang. Osteoporosis adalah suatu penyakit yang ditandai dengan massa tulang yang rendah dan terjadi kemunduran struktur jaringan tulang, sehingga menyebabkan kerentanan tulang dan peningkatan risiko patah tulang. Minum susu saat remaja diharapkan dapat meningkatkan massa tulang. Penelitian ini bertujuan untuk menentukan hubungan antara pengetahuan tentang osteoporosis dan konsumsi susu pada murid SMA.

\section{METODE}

Sebuah penelitian analitik observasional dengan pendekatan desain cross sectional digunakan dengan mengikutsertakan 182 siswa dan siswi Sekolah Menegah Atas (SMA). Data dikumpulkan menggunakan kuesioner yang meliputi karakteristik subjek (usia, gender dan pendidikan orang tua. Pengetahuan mengenai osteoporosis dan konsumsi susu diukur menggunakan kuesioner. Uji chi-square digunakan untuk analisis data dan tingkat kemaknaan yang digunakan besarnya 0,05 .
\end{abstract}

\section{HASIL}

Sebanyak 128 (70,32\%) subjek memiliki pengetahuan tentang osteoporosis yang baik dan $36(19,8)$ subjek minum susu sebanyak 2-3 gelas per hari. Pada subyek yang berpengetahuan tentang osteoporosis rendah didapatkan 27 orang $(50,0 \%)$ tidak minum susu lebih besar secara bermakna dibandingkan subyek yang berpengetahuan osteoporosis tinggi sebanyak 5 orang $(3,9 \%)$. Terdapat hubungan yang bermakna antara pengetahuan tentang osteoporosis dan konsumsi susu pada murid SMA $(\mathrm{p}=0,000)$.

\section{KESIMPULAN}

Penelitian ini menunjukkan bahwa terdapat hubungan yang bermakna antara pengetahuan tentang osteoporosis dan konsumsi susu pada murid SMA. Penyuluhan mengenai konsumsi minum susu harus dilakukan pada murid SMA untuk meningkatkan pengetahuannya mengenai osteoporosis.

Kata kunci : pengetahuan osteoporosis, konsumsi susu, murid SMA
${ }^{1}$ Program Studi Kedokteran,

Fakultas Kedokteran,

Universitas Trisakti

${ }^{2}$ Departemen Ilmu Kesehatan

Masyarakat,

Fakultas Kedokteran,

Universitas Trisakti

\section{Korespondensi:}

Adi Hidayat

Departemen Ilmu Kesehatan

Masyarakat,

Fakultas Kedokteran,

Universitas Trisakti

Email: hidayat.adi@trisakti.ac.id

J Biomed Kes 2018;1(1):35-42

DOI: 10.18051/JBiomedKes.2018.

v1.35-42

pISSN: 2621-539X / eISSN: 2621-5470

Artikel akses terbuka (open access) ini didistribusikan di bawah lisensi Creative Commons Attribution 4.0 International (CC-BY 4.0) 


\section{ABSTRACT}

\section{Low osteoporosis knowledge decrease milk consumption in senior high school students}

\section{BACKGROUND}

Milk is a main source of calcium and phospor which is very important for bone formation. Milk consumption during adolescence is recommended to promote peak bone mass and thereby reduce fracture risk in later life. Osteoporosis is a disease that can be marked with poor bone mass and decline the structure of bone tissue, that can lead to vulnerability of bone and increased risk of bone fracture. The objective of this study was to determine the relationship between knowledge of osteoporosis and milk consumption in senior high school students.

\section{METHODS}

An analytic observational study with a cross-sectional design was performed involving 182 senior high school students. Data were collected using a questionnaire on age sex and parents's education. Knowledge about osteoporosis and milk consumption behavior were measured using a questionnaire. Chi-square test was used to analyse the data and a significance test at $\mathrm{p}<0.05$.

\section{RESULT}

In total, $128(70.32 \%)$ senior high school students scored highly on knowledge of osteoporosis and 36 (19.8) drink 2-3 glass of milk per day. High school students with low osteoporosis knowledge 27 (50.0\%) did not drink milk significantly higher than subjects with high osteoporosis knowledge 5 (3.9\%). Chi-Square test showed a significant relationship between knowledge of osteoporosis and milk consumption among senior high school students $(\mathrm{p}=0.000)$.

\section{CONCLUSION}

This study demonstrated that there was a significant correlation between knowledge of osteoporosis and milk consumption among senior high school students. Promotion of milk consumption must be done among senior high school students to increase their knowledge on osteopororisis.

Keywords : knowledge of osteoporosis, milk consumption, senior high school students

\section{PENDAHULUAN}

Susu adalah minuman yang sangat menyehatkan dengan kandungan gizinya yang lengkap. Susu juga merupakan sumber utama kalsium dan fosfor yang sangat penting untuk pembentukan tulang. (1) Kandungan dalam susu terdiri dari air, protein, lemak, karbohidrat, vitamin A, C, $\mathrm{D}$, dan mineral. ${ }^{(2)}$ Selain bermanfaat sebagai pembentukan tulang, susu juga memiliki berbagai manfaat antara lain meningkatkan tinggi badan, mencegah patah tulang dan menurunkan resiko osteoporosis. ${ }^{(3)}$ Untuk itu, susu sangat baik dikonsumsi pada masa remaja, karena pada masa remaja terjadi pembentukan jaringan tulang yang merupakan masa persiapan untuk mencapai puncak pertumbuhan massa tulang. ${ }^{(4)}$

Namun, faktanya saat ini konsumsi susu pada anak remaja memiliki prevalensi yang rendah sebanyak $30,0 \%{ }^{(5)}$ Kencenderungan konsumsi susu dari tahun ke tahun tampaknya memang ada kemajuan, namun kemajuannya relatif lambat. Kebiasaan minum susu masyarakat di Indonesia termasuk terendah di Asia Tenggara. Di negara-negara maju susu telah menjadi minuman sehari-hari, sedangkan di Indonesia tingkat konsumsi susu masih terbilang sangat rendah, hanya mencapai 7,9 liter per kapita per tahun, di Malaysia sudah mencapai 23 liter per kapita per tahun, sementara di Filipina tingkat konsumsi susu mencapai 25 liter per kapita per tahun. ${ }^{(6)}$

Tingkat konsumsi susu rendah dapat disebabkan oleh berbagai hal. Diantaranya susu dianggap mahal, kurangnya pemahaman akan manfaat susu, sehingga menurunkan perilaku minum susu di masyarakat. ${ }^{(7)}$ Rendahnya konsumsi susu di masyarakat terutama di kalangan remaja dinilai berdampak pada meningkatnya resiko kurangnya kepadatan tulang dan beresiko besar terjadinya patah tulang dan osteoporosis pada saat dewasa dan usia lanjut. ${ }^{(8)}$

Osteoporosis adalah suatu penyakit yang ditandai dengan massa tulang yang rendah dan terjadi kemunduran struktur jaringan tulang, sehingga menyebabkan kerentanan 
tulang dan peningkatan risiko patah tulang. (9) Patah tulang pada kondisi osteoporosis bisa terjadi pada tulang yang memiliki banyak trabekula, yaitu tulang punggung, pinggul, pergelangan tangan. ${ }^{(10)}$ Patah tulang akibat osteoporosis dapat mengakibatkan meningkatkan beban sosioekonomi berupa biaya pengobatan yang besar. ${ }^{(11)}$ Untuk itu penyakit ini merupakan masalah kesehatan yang perlu mendapatkan perhatian khusus.

Osteoporosis disebut juga silent disease atau silent thief, karena osteoporosis seringkali tanpa ada gejala dan tidak selalu terdiagnosa, bahkan osteoporosis baru disadari jika telah terjadi perubahan bentuk tulang atau telah terjadinya patah tulang karena trauma maupun spontan. $^{(12)} \quad$ Penyakit osteoporosis lebih banyak menyerang wanita dari pada pria. Pada wanita densitas tulangnya lebih rendah dibandingkan pria dengan perbandingan 1:6. (13) Pada wanita juga lebih mudah kehilangan mineral tulang dibandingkan pada pada pria serta wanita memiliki usia hidup lebih panjang dari dibandingkan pria, sehingga semakin tua umur wanita angka kejadian osteoporosis akan semakin meningkat. Pada wanita juga mengalami menopause yang dimana kekurangan estrogen lebih banyak. ${ }^{(14)}$ Penyakit osteoporosis menduduki peringkat kedua setelah penyakit jantung sebagai masalah utama kesehatan didunia. ${ }^{(15)}$

Dari data Internasional Osteoporosis Foundation (IOF) lebih dari 30\% wanita di seluruh dunia mengalami resiko seumur hidup untuk patah tulang akibat osteoporosis, bahkan mendekati 40\%, sedangkan pada pria resikonya hanya $13 \% .^{(16)}$ Berdasarkan analisis data Kementerian Kesehatan Republik Indonesia, menyatakan bahwa angka prevalensi osteopenia (osteoporosis dini) sebesar $41,7 \%$ dan prevalensi osteoporosis sebesar $10,3 \%$. $^{(17)}$

Data di atas menunjukkan bahwa prevalensi osteoporosis cukup tinggi. Untuk itu perlu dilakukan pencegahan sedini mungkin atau paling sedikit menunda kejadian osteoporosis dengan membudayakan perilaku hidup sehat. Perilaku seseorang dipengaruhi dengan pengetahuan yang dimiliki. Semakin baik pengetahuan seseorang, semakin baikjuga perilakunya. ${ }^{(18)}$ Berdasarkan hasil penelitian yang dilakukan oleh Wadolowska dkk. ${ }^{(19)}$ menunjukkan bahwa terdapat hubungan konsumsi susu pada masa kanak-kanak dan remaja dapat memperbaiki kepadatan mineral tulang dan mengurangi risiko osteoporosis pada wanita dewasa. Namun hasil penelitian ini berbeda dengan hasil penelitian oleh Feskanich dkk. ${ }^{(20)}$ menunjukkan bahwa konsumsi susu remaja tidak berhubungan dengan fraktur pinggul.

Berbagai penelitian telah meneliti hubungan antara pengetahuan osteoporosis dengan perilaku konsumsi susu. Namun masih banyaknyaketidakserasian antara pengetahuan osteoporosis dengan perilaku konsumsi susu setiap harinya pada masyarakat Indonesia, khususnya pada remaja. Berdasarkan uraian diatas maka perlu dilakukan penelitian yang bertujuan untuk menentukan hubungan antara pengetahuan tentang osteoporosis dan konsumsi susu pada murid SMA.

\section{METODE}

\section{Jenis penelitian}

Penelitian analitik observasional dengan pendekatan desain cross sectional telah dilakukan selama bulan Juli sampai Oktober 2017 di Madiun, Jawa Timur.

\section{Subjek penelitian}

Sebanyak 182 siswa-siswi SMA Negeri 2 Mejayan merupakan subjek penelitian ini. Penentuan besar sampel dilakukan menggunakan rumus :

$$
n=Z_{\alpha}{ }^{2}(p x q) / d^{2}
$$

Prevalensi konsumsi susu pada remaja beasrnya $30,0 \%{ }^{(5)}$, pada tingkat kemaknaan sebesar 95\% dan keakuratan sebesar 0,05, maka besar sampel yang diperlukan besarnya 322. Jumlah siswa siswi SMA X dan XI jumlahnya 310 , serta drop-out diperkirakan sebesar 15\%. Maka besar sampel yang dibutuhkan penelitian in besarnya 182 siswasiswi SMA. 
Pemilihan sampel dilakukan secara cluster sampling dan simple random sampling pada semua siswa dan siswi SMA Negeri 2 Mejayan. Kriteria inklusi pada penelitian ini adalah siswa-siswi kelas X dan XI SMA yang mampu berkomunikai dan bersedia mengisi informed concent, sedangkan kriteria eksklusi adalah siswa - siswi kelas X dan XI SMA yang terdiagnosis alergi terhadap susu.

\section{Pengumpulan data}

Seluruh responden yang memenuhi kriteria inklusi dan eksklusi dilakukan wawancara dengan menggunakan 3 jenis kuesioner. Kuesioner pertama mencakup data mengenai usia, gender dan pendidikan orang tua. Pengetahuan tentang osteoporosis diukur menggunakan kuesioner yang telah divalidasi oleh Wadolowska dkk. ${ }^{(19)}$

Kuesioner kedua ini terdiri dari 14 item pertanyaan dan setiap item diberikan skor 1 bila jawaban benar dan 2 bila jawaban salah. Variabel pengetahuan tentang osteoporosis dibagi menjadi dua kategori yaitu baik dan kurang. Kuesioner ketiga berupa 24 hour food frequency questionnaire (FFQ) digunakan untuk mengukur komsumsi susu. Variabel komsumsi susu dibagi menjadi 4 kategori : i). tidak minum susu;ii). minum 1 gelas/hari;iii). minum 2-3 gelas/hari ; dan iv). Minum $<2$ gelas/minggu.

\section{Analisis data}

Analis data yang digunakan dalam penelitian ini adalah analisis univariat dan analisis bivariat yang dilakukan secara bertahap. Analisis univariat digunakan untuk mendeskripsikan distribusi dari masingmasing variabel yang diteliti yaitu umur, jenis kelamin, pendidikan orang tua, pengetahuan tentang osteoporosis dan konsumsi susu. Analisis bivariat digunakan untuk menguji adanya hubungan antara variabel umur, jenis kelamin, pendidikan orang tua, pengetahuan tentang osteoporosis dan konsumsi susu. Uji statistik yang digunakan adalah uji ChiSquare. Tingkat kemaknaan yang digunakan besarnya 0,05 .

\section{Kaji etik}

Protokol penelitian ini telah memperoleh ethical clearance dari Komisi Etik Riset Fakultas Kedokteran Universitas Trisakti dengan No.45/KER-FK/VII/2017.

\section{HASIL}

\section{Distribusi beberapa variabel penting responden}

Tabel 1. Distribusi beberapa variabel penting responden penelitian $(n=182)$

\begin{tabular}{lcc}
\hline \multicolumn{1}{c}{ Variabel } & $\mathrm{n}$ & $\%$ \\
\hline $\begin{array}{l}\text { Jenis kelamin } \\
\text { Laki-laki }\end{array}$ & 75 & 41,2 \\
$\quad$ Perempuan & 107 & 58,8 \\
Usia (tahun) & & \\
$\quad$ 15-16 & 95 & 52,2 \\
17-18 & 87 & 47 \\
Pendidikan orang tua & & \\
$\quad$ Tidak sekolah & 0 & 0 \\
SD-SMP & 44 & 24,2 \\
$\quad$ SMA-Perguruan Tinggi & 138 & 75,8 \\
Pengetahuan Osteoporosis & & \\
Kurang & 54 & 29,7 \\
Baik & 128 & 70,3 \\
Konsumsi susu & & \\
$\quad$ Tidak minum susu & 32 & 17,6 \\
1 gelas/hari & 81 & 44,5 \\
2-3 gelas/hari & 36 & 19,8 \\
$\quad<2$ gelas/minggu & 33 & 18,1 \\
\hline
\end{tabular}

Murid perempuan besarnya 107 orang (58,8\%), mayoritas berusia 15- 16 tahun sebanyak 95 orang $(52,2 \%)$. Pendidikan orang tua siswa pada penelitian ini yang berpendidikan SMA dan Perguruan tinggi sebanyak 138 orang $(75,8 \%)$.

Murid yang memiliki pengetahuan baik tentang osteoporosis sebanyak 128 $(70,3 \%)$ dan sebanyak $150(82,4 \%)$ murid minum susu serta mengonsumsi susu paling banyak yaitu sebanyak 81 orang $(44,5 \%)$ minum susu 1 gelas / hari (Tabel 1). 
Hubungan karakteristik sosiodemografi dan konsumsi susu dengan penegtahuan tentang osteoporosis

Murid laki-laki yang tidak mengonsumsi susu sebanyak 8 orang $(10,7 \%)$ lebih rendah dibandingkan murid perempuan sebesar 24 (22.4\%), tetapi tidak bermakna secara statistik $(\mathrm{p}=0,176)$. Umur murid dan pendidikan orang tua tidak berhubungan secara bermakna dengan konsumsi susu $(p=0,067$ dan $p=0,411)$.

Pada murid yang berpengetahuan tentang osteoporosis kurang didapatkan 27 orang $(50,0 \%)$ tidak minum susu lebih besar secara bermakna dibandingkan murid yang berpengetahuan osteoporosis baik sebanyak 5 orang $(3,9 \%)(p=0,000)$.

\section{PEMBAHASAN}

Hasil penelitian kami menunjukkan sebanyk 83/182 (44,2\%) murid perempuan SMA sudah minum susu. Hasil ini tidak berbeda dibandingkan penelitian di Iran pada murid perempuan SMA yaitu sebesar $42,9 \%$. (21) Hasil ini menunjukan masih rendahnya murid perempuan SMA minum susu yang sangat bermanfaat bagi pertumbuhan massa tulangnya. Hasil penelitian kami menunjukkan sebanyak $150(82,4 \%)$ murid SMA minum susu. Hasil ini lebih tinggi dibandingkan penelitian di Hongkong, yang menunjukkan sebanyak $65.7 \%$ remaja yang obesitas minum susu secara teratur. ${ }^{(22)}$ Subjek penelitian pada kedua penelitian berbeda, pada penelitian kami tidak diteliti banyaknya murid SMA yang mengalami obesitas seperti penelitian di Hongkong. Apabila diteliti murid SMA yang obesitas tentu banyaknya komsnumsi susu menjadi lebih rendah.

Dari 182 subyek didapatkan yang berpengetahuan baik tentang osteoporosis pada penelitian ini didapatkan jumlah sebanyak 128 orang (70,3\%). Hasil pada penelitian ini sesuai dengan hasil dari penelitian Ismail yaitu didapatkan hasil pengetahuan baik tentang ostoporosis sebanyak 61,9\%.. ${ }^{(23)}$ Hasil yang tidak

Tabel 2. Hubungan antara karakteristik sosiodemografi dan pengetahuan tentang osteporosis dengan konsumsi susu pada murid SMA $(\mathrm{n}=182)$

\begin{tabular}{|c|c|c|c|c|c|c|}
\hline \multirow[b]{2}{*}{ Variabel } & \multirow{2}{*}{$\begin{array}{c}\text { Tidak } \\
\text { minum } \\
\text { susu (\%) }\end{array}$} & \multicolumn{2}{|c|}{ Konsumsi susu } & \multirow[b]{2}{*}{$\begin{array}{c}<2 \text { gelas/ } \\
\text { minggu }(\%)\end{array}$} & \multirow[b]{2}{*}{ Total (\%) } & \multirow[b]{2}{*}{$\mathrm{P}$} \\
\hline & & $\begin{array}{l}1 \text { gelas/ } \\
\text { hari }(\%)\end{array}$ & $\begin{array}{l}\text { 2-3 gelas/ } \\
\text { hari }(\%)\end{array}$ & & & \\
\hline \multicolumn{7}{|l|}{$\begin{array}{l}\text { Jenis } \\
\text { kelamin }\end{array}$} \\
\hline Laki-laki & $8(10,7)$ & $37(49,3)$ & $14(18,7)$ & $16(21,3)$ & $75(100,0)$ & \\
\hline Perempuan & $24(22,4)$ & $44(41,1)$ & $22(20,6)$ & $17(15,9)$ & $107(100,0)$ & 0,176 \\
\hline \multicolumn{7}{|l|}{ Usia } \\
\hline 15-16 tahun & $23(24,2)$ & $42(44,2)$ & $15(15,8)$ & $15(15,8)$ & $95(100,0)$ & \\
\hline 17-18 tahun & $9(10,3)$ & $39(44,8)$ & $21(24,1)$ & $18(20,7)$ & $87(100,0)$ & 0,067 \\
\hline \multicolumn{7}{|l|}{$\begin{array}{l}\text { Pendidikan } \\
\text { orang tua }\end{array}$} \\
\hline SD-SMP & $11(25,0)$ & $17(38,6)$ & $7(15,9)$ & $9(20,5)$ & $44(100,0)$ & \\
\hline $\begin{array}{l}\text { SMA- } \\
\text { Perguruan } \\
\text { Tinggi }\end{array}$ & $21(15,2)$ & $64(46,4)$ & $29(21,0)$ & $24(17,4)$ & $138(100,0)$ & 0,411 \\
\hline \multicolumn{7}{|l|}{$\begin{array}{l}\text { Pengetahuan } \\
\text { Osteoporosis }\end{array}$} \\
\hline Kurang & $27(50,0)$ & $18(33,3)$ & $2(3,7)$ & $7(13,0)$ & $54(100,0)$ & \\
\hline Baik & $5(3,9)$ & $63(49,2)$ & $34(26,6)$ & $26(20,3)$ & $128(100,0)$ & $0,000 *$ \\
\hline
\end{tabular}


berbeda ditunjukkan pada penelitian di United Arab Emirates, sebanyak 88.3\% yakin bahwa osteoporosis merupakan penyakit yang serius. ${ }^{(24)}$ Penelitian kami menunjukkan terdapat hubungan secara bermakna antara pengetahuan tentang osteoporosis dan konsumsi susu. Hal ini sesuai dengan penelitian yang dilakukan oleh Wadolowska dkk. ${ }^{(19)}$ menunjukan bahwa terdapat hubungan konsumsi susu pada masa kanak - kanak dan remaja dapat memperbaiki kepadatan mineral tulang dan mengurangi risiko osteoporosis pada wanita dewasa.

Semakin baik pengetahuan seseorang tentang osteoporosis, semakin baik juga perilakunya dalam mengonsumsi susu. (18) Susu bermanfaat sebagai pembentukan tulang, meningkatkan tinggi badan, mencegah patah tulang dan menurunkan resiko osteoporosis. ${ }^{(3)}$

Sebuah studi meta-analisis menunjang peran kalsium dan vitamin D untuk mencegah terjadinya osteoporosis. ${ }^{(25)}$ Susu yang kaya akan sumber kalsium, vitamin D dan protein dapat menurunkan risiko terjadinya osteoporosis.

Penelitian ini memiliki beberapa keterbatasan. Pertama, rancangan penelitian yang digunakan adalah cross-sectional yang tidak dapat menggambarkan hubungan sebab akibat. Kedua, penelitian ini tidak mengukur secara kuantitatif jumlah kalsium yang diminum.

\section{KESIMPULAN}

Pengetahuan tentang osteoporosis yang rendah menurunkan konsumsi susu pada murid SMA. Perlu dilakukan penelitian lebih lanjut dengan menggunakan rancangan penelitain yang lebih baik, misalkan cohort dan mengukur jumlah kalsium yang diminum para murid SMA.

\section{UCAPAN TERIMA KASIH}

Kami mengucapkan terima kasih kepada semua murid SMANegeri 2 Mejayan,
Madium, Jawa Timur yang telah bersedia menjadi subjek pada penelitian ini. Dan kepada semua pihak yang telah membantu terlaksananya penelitian ini kami ucapkan terima kasih.

\section{KONFLIK KEPENTINGAN}

Para peneliti tidak memiliki konflik kepentingan pada penelitian ini.

\section{KONTRIBUSI KEPENGARANGAN}

IAP dan AH berkontribui pada penulisan naskah, pengumpulan dan analisi data. AH berkontribusi pada perbaikan naskah. Semua penulis telah membaca naskah terakhir dan memberikan persetujuannya.

\section{DAFTAR REFERENSI}

1. Bischoff - Ferrari H A, Dawson Hughes B, Baron J A, et al. Calcium intake and hip fracture risk in men and women: a meta-analiysis of prospective cohort studies and randomized controlled trials. Am J Clin Nurt 2007; 86: $1780-90$. doi : 10.1093/ajen/86.5.1780.

2. Ross AC, Caballero B, Causins RJ. Modern Nutrition in Health Disease. 11th ed. United States: Lippincott Williams \& Wilkins ; 2014.

3. Okade T. Effect of cow milk consumption on longitudinal height gain in children. Am J Clin Nutr 2004;80: 1088-9. doi : 10.1093/ajcn/80.4.1088a.

4. Loro ML, Sayre J, Roe TF, Goran MI, Kaufman FR, Gilsanz V. Identifikasi dini anak - anak cenderung mencapai puncak tulang dan osteoporosis di kemudian hari. J Clin Endocrinol Metab2000; 85: 3908-18. doi : 10.1210/ jcem.85.10.6887.

5. Nasar MF, Abdelkader AM, Al-Refaee FA, et al. Pattern of beverage intake and milk and dairy product sufficiency among high-school students in Kuwait. EMHJ.2014;20:738-44. 
6. Dinas Peternakan Jawa $B$ a $\quad r \quad a \quad t$. Kebiasaan minum susu masyarakat Indonesia terendah di Asia Tenggara. Bandung : . Dinas Peternakan Jawa Barat;2017.

7. Wirakartakusumah MA. Sifat fisik bahan pangan. Bogor : Departemen Pendidikan dan Kebudayaan. Direktorat Jenderal Pendidikan Tinggi, Pusat Antar Universitas Pangan dan Gizi,IPB;2011.

8. Kalwarf H. Milk intake during childhood and adolesense, adult bone density and osteoporotic fracture in US women. Am J Clin Nutr 2003; 77 : 256-7. Doi : 10.1093/ajcn/77.1.257.

9. Hemastuti A, Muflihah I. Hubungan indeks massa tubuh, massa lemak tubuh, asupan kalsium, aktivitas fisik dan kepadatan tulang pada wanita dewasa muda. J Nutr Coll 2012;1 : 435-50.

10. Internasional Osteoporosis Foundation Osteoporosis and Musculoskeletal Disorders. What is osteopororsis? Available at:http://www.iofbonehealth. org/what- is-osteoporosis. Accessed Mei 19, 2017

11. Burge RT, Dawson-Hughes B, Solomon $\mathrm{D}$, et.al. Incidence and economic burden of osteoporosis fracture in United States, 2005-20025. J_Bone Min Res_2007 : 22 ; 465-75

Doi : 10.1359.jbmr.061113.

12. Jahari AB, Prihatini S. Risiko osteoporosis di Indonesia. Gizi Indonesia. E- Journal Persegi 2007 : 1; 243-67.

13. Fawzy T, Muttappallymyalil J, Sreedharan J, et al. Association between body mass index and bone mineral desity in patients refered for dual- energy X-ray absorptiometry Scan in Ajman, UAE. J Osteoporos 2011, Article ID 876309, 4 pages. doi:10.4061/2011/876309.

14. Barling PM, Osteoporosis an increasingly important issue for both young and aging citizens of Malaysia. Int e-J Sci Med Edu 2013;7: 1-3.
15. Kanis JA. On behalf of the Word Health Organization scientific group: assessment of Osteoporosis at the primary helth-care level, technical report. UK: WHO Collaborating Centre, University of Sheffield.2007

16. National Osteoporosis Foundation Fast facts. Available at: http://www.nof.org/ node/40. Accessed Mei 11, 2017.

17. Pusat Data dan Informasi Kementerian Kesehatan RI. Data dan kondisi penyakit osteoporosis di Indonesia. Jakarta : Pusat Data dan Informasi Kementerian Kesehatan RI;2015.

18. Notoatmodjo S. Promosi kesehatan dan ilmu perilaku. Jakarta: Rineka Cipta ; 2007.

19. Wadolowska L, Sobas K, Szczepanska JW, et al. Dairy Products, Dietary Calcium and Bone Health : Possibility of Prevention of Osteoporosis in Women : Ther Polish Experience.

Nutrients.2013;5:2684-707.Doi;103390/ nu5072684

20. Feskanich D, Bischoff-Ferrari HA, Frazier L, Willett WC. Milk Consumption During Teenage Years and Risk of Hip Fractures in Older Adults. JAMA Pediatr.2014; 168(1) 54-60. Doi:1001/jamapediatrics.2013.3821.

21. Ghajari $\mathrm{H}$, Ghaderi $\mathrm{N}$, Valizadeh $\mathrm{R}$, Shakerinejad G, Haghighizadeh MH. Knowledge, attitude and nutritional behavior of female high school students about consumption of calcium-rich foods in Khorramshahr city, South West of Iran. Int J Pediatr 2016; 4: 3837-46. DOI:10.22038/ijp.2016.7795.

22. Lin SL, Tarrant M, Hui LL, et al. The role of dairy products and milk in adolescent obesity: evidence from Hong Kong's "children of 1997" birth cohort. PLoS ONE 2012;7: e52575. doi:10.1371/ journal.pone.0052575.

23. Darout IA, Alamir A, Sultana S. Osteoporosis Knowledge and Related Health Behavior among Women in Jazan Region, Kingdom of Saudi Arabia. J Contemp Dent Pract 2017;18: 378-2. 10.5005/jp-journals-10024-2050. 
24. Al-Hemyari SS, Shamssain M. Knowledge, believes and behaviors of university students toward osteoporosis. EJPMR 2017;4 : 1-9.

25. Tang BMP, Eslick GD, Nowson C, Smith C, Bensoussan A. Use of calcium or calcium in combination with vitamin D supplementation to prevent fractures and bone loss in people aged 50 years and older: a meta-analysis. Lancet 2007;370:657-66. doi:10.1016/s01406736(07)61342-7. 